\title{
Indonesian Economic Diplomacy in Strengthening Coffee Exports in the United States Market 2012-2017
}

\author{
H. Hervinaldy \\ Universitas Muhammadiyah Yogyakarta \\ Email:@hervinaldyzein@yahoo.co.id
}

\begin{abstract}
Several policies related to coffee have been implemented by the Indonesian government and in collaboration with various parties; one of the steps is to introduce, invite, and participate in major events to introduce Indonesian coffee. The development of the coffee industry in Indonesia currently does not only supports the upstream but also has moved downstream (packaging, baristas, and e-commerce), which results in added value. This study aims to discuss the diplomacy strategies applied by Indonesia to strengthening coffee exports in the United States and what factors support these diplomacy strategies. From this study, it could be concluded that Indonesia's diplomacy strategy will open more opportunities for foreign exchange-earners and introduce Indonesia's coffee characteristics. Indonesian coffee production is expected to continue to be stable and increase, given the coffee needs of the United States community and the United States' factor as the largest importer of Indonesian coffee. In 2013, Indonesia was ranked third as the world's largest coffee producer before being overtaken by Colombia in 2015. To date, Brazil has been strong as the world's coffee giant, followed by Vietnam in the second place, Colombia in third place, and Indonesia in fourth, respectively. It was caused by two factors: unstable national coffee production and an increase in domestic coffee consumption.
\end{abstract}

Keywords: Economic Diplomacy, Export Strengthening, Coffee Exports, Diplomacy Strategy

\section{Abstrak}

Beberapa kebijakan terkait kopi telah dilaksanakan oleh pemerintah Indo- 
nesia dan bekerjasama dengan berbagai pihak; salah satu langkahnya adalah memperkenalkan, mengajak, dan berpartisipasi dalam acara-acara besar untuk memperkenalkan kopi Indonesia. Perkembangan industri kopi di Indonesia saat ini tidak hanya mendukung hulu tetapi juga telah bergerak ke hilir (kemasan, barista, dan e-commerce) yang menghasilkan nilai tambah. Penelitian ini bertujuan untuk membahas strategi diplomasi yang diterapkan Indonesia untuk memperkuat ekspor kopi di Amerika Serikat dan faktor apa saja yang mendukung strategi diplomasi tersebut. Dari penelitian ini dapat disimpulkan bahwa strategi diplomasi Indonesia akan membuka lebih banyak peluang bagi penghasil devisa dan memperkenalkan karakteristik kopi Indonesia. Produksi kopi Indonesia diperkirakan akan terus stabil dan meningkat, mengingat kebutuhan kopi masyarakat Amerika Serikat dan faktor Amerika Serikat sebagai importir terbesar kopi Indonesia. Pada tahun 2013, Indonesia menduduki peringkat ketiga sebagai produsen kopi terbesar dunia sebelum disusul oleh Kolombia pada tahun 2015. Hingga saat ini, Brasil masih kuat sebagai raksasa kopi dunia, disusul Vietnam di peringkat kedua, Kolombia di peringkat ketiga, dan Indonesia di peringkat ketiga. keempat, masing-masing. Hal itu disebabkan oleh dua faktor: produksi kopi nasional yang tidak stabil dan peningkatan konsumsi kopi dalam negeri.

Kata Kunci: Diplomasi Ekonomi, Penguatan Ekspor, Ekspor Kopi, Strategi Diplomasi

\section{INTRODUCTION}

Coffee, which is one of the Indonesian economy wheels as a global commodity and the large consumption of coffee in the United States, is a valuable asset for Indonesia. Arabica and Robusta coffees have become the prima donna of Indonesia's coffee exports. In 2013, Indonesia occupied the third position as the world's largest coffee producer before being overtaken by Colombia in 2015 . Until now, Brazil has been strong as the world's coffee giant, followed by Vietnam and Colombia in second and third place, and Indonesia in fourth place, respectively. It was due to two factors: unstable national coffee production and an increase in domestic coffee consumption. On the other hand, although Indonesia is one of the world's largest producers or exporters, most of the processed 
forms exported have been coffee beans. When seen from the increase in added value in exports, Indonesia should have begun to focus on the progress of coffee production, including down streaming so that coffee commodity exports provide added value and profit, which gradually continues to grow. In 2012, Indonesia's coffee exports to the United States experienced a big jump, with an increase of $8 \%$ compared to the previous year with total exports of 69.7 thousand tons (Badan Pusat Statistik, 2017).
Indonesian coffee production is expected to be stable and increase every year, given the need for coffee in the United States. The United States is the largest coffee importer from Indonesia, while other export destinations are Japan, Germany, and Italy. Although the United States is the largest importing country from Indonesia, in its development, Indonesia's coffee exports to the United States continued to experience fluctuations in export volume and value during the 20122017 period.

\section{Graph of Indonesian Coffee Exports to the United States (2012-2017 Period) \\ Net weight (Tona)}

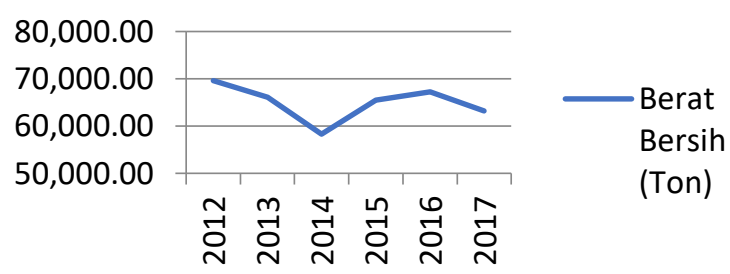

Source: Data Processing

Based on the above facts, despite experiencing fluctuations due to several factors, Indonesian coffee production is a commodity with high competitiveness compared to foreign coffee commodities and has the potential to increase foreign exchange earnings. The development of Indonesian coffee exports to the United States from 2012-2017 experienced fluctuations, where the highest export occurred in 2012, amounting to $69,651.6$ tons with a value of USD 330,814.7 (Badan Pusat Statistik, 2017).

\section{Problem Formulation}

Based on the problem description above, a research formula 
could be drawn with the following questions:

How is Indonesia's diplomacy towards increasing promotion and exports of coffee commodities in the United States?

\section{RESEARCH METHODS}

This research focused on qualitative research methods, which generally referred to the nonnumerical collection and strategy or data analysis techniques. Qualitative methods were used by the authors to get a better understanding of specific events, phenomena, regions, countries, organizations, or individuals. However, it could not be denied that the author would find numerical data, considering that this research examined economic diplomacy strategies towards strengthening coffee exports applied by Indonesia to bring competitiveness and increase coffee exports.

\section{Literature Review}

Liberalism's view of trade and economic relations states that each individual is interdependent. (Jackson \& Sorensen, 2014). In the coffee trade, Indonesia is one of the largest coffee producers globally, while the United States is one of the countries whose people consume coffee in large numbers (Kementrian Perdagangan Republik Indonesia, 2013). The Indonesian coffee trade to the United States provides evidence that interdependence occurs to meet each country or individual needs (Dr.Agus Subagyo, 2019).

Liberalism is an ideology or political view that states equal rights and freedoms are owned by every individual. Traditions and liberal views in international relations are closely related to the presence of the modern liberal state. John Locke saw the great potential for human progress in civil society and a modern capitalist economy; both can develop in countries that guarantee individual liberty. The modernization process launched by the scientific revolution resulted in an increase in technology, and as such, more efficient ways of producing goods and controlling nature emerged (Jackson \& Sorensen, 2014).

John Locke argues that the state arose to guarantee its citizens' freedom and then allow them to live their lives and get their happiness without undue interference from others. This argument was later expanded by Jeremy Bentham, an 18th-century English philosopher who gave rise to international law. He believes that international 
law is in the rational interest of constitutional states to believe in international law regarding foreign policy. Later, this view was further expanded by the 18th-century German philosopher Immanuel Kant, who thought that the world of such a constitutional state and countries that respect each other or known as republics could ultimately establish lasting peace in the world (Jackson \& Sorensen, 2014).

Economic diplomacy is a strategy implemented by many developing countries in cooperating with countries with greater global power, both political and economic power. From the research case that raised the issue of Indonesia's economic diplomacy in strengthening coffee exports to the United States, it could have an impact on national production competition and policy reforms and coffee exports because Indonesia is one of the world's largest coffee exporting countries. Economic diplomacy also includes the image of a trademark or brand image. From the research case of Indonesian coffee so far, more of it was exported as coffee beans without a trademark. By using this branding image, it is hoped that Indonesian coffee will be better known in the United States market.

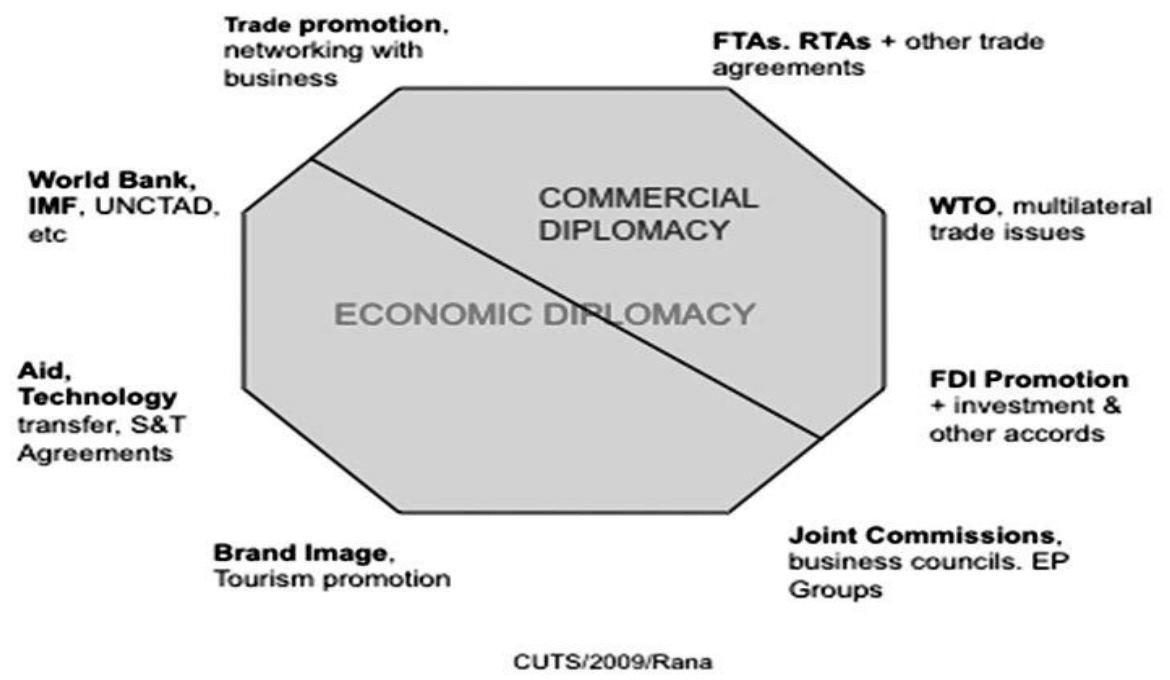

Figure 1. Economic Diplomacy Scope

Source: Kishan S Rana. The Role of Embassies (2013) 
In Kishan S Rana's article, he explained that the image of the country of origin underpins most diplomatic activities (Kishan). Wally Olins asserts that countries need a new image because changing realities leave perceptions far behind (Olins 1999). It is especially true of developing and transitional countries, which have seen dramatic changes but have been underestimated abroad. Country branding is about presenting a country or region in a strong, attractive, and distinct way. Branding works when it projects and amplifies a changing reality, but it can be counterproductive if it does not take root in reality. The key is to use a solid and straightforward central idea and capture the country's unique qualities. According to Peters and Zinkhan, the importance of a brand image is that consumers, buyers, and the market can know and be more confident about the products being offered to open global interest (Edited by Frost \& Laing, 2018).

In carrying out economic diplomacy, it is also necessary to apply the concept of competitive advantage. According to Michel. E. Porter, it is a theory that suggests competitive advantage obtained through an institution or company's characteristics in competing with other institutions or companies in the same field (Porter, 1996). For this reason, companies are required to have a competitive advantage. As said by Simic, Bolfek, \& Stoic, competitive advantage is needed to satisfy customers so that they will receive a higher value from the products produced; at the same time, it can also provide large revenues as demanded by business owners on the company management, where the need to achieve it can be met with the company's productivity, high-quality applications, and the company's lowest possible production costs (SIMIĆ, BOLFEK, \& STOIĆ, 2008). What is meant by competitive advantage here is when a company or institution can provide service benefits and products of the same quality as those produced by other competing companies or institutions. In other words, Indonesia must be able to compete with other coffee exporting countries in the quality and quantity of coffee produced.

\section{RESULTS AND DISCUSSION}

Indonesia's coffee farming, which is dominated by the Robusta variety, has resulted in Indonesia becoming one of the exporting countries of Robusta coffee. Similar 
to Indonesia, Vietnam's coffee production is mainly dominated by Robusta. For the Arabica variety, it is produced more by the two-world coffee-producing countries, namely Brazil, which occupied the first position as a world coffee producer and Colombia in third place related to coffee production (International Coffee Organization, 2018).

If divided and positioned into sections, the coffee consuming countries in the world are divided into four: The United States (US), which is a large country with high needs, followed by the European Economic Community (EEC), including Italy, which has espresso coffee as its country's identity. Then, it is followed by technologically advanced countries, namely Japan and other countries. In 10 years, the world coffee imports carried out by each group of countries were $35.50 \%$ by the United States, $44.50 \%$ by the European Economic Community, $5.95 \%$ by Japan, and $14.05 \%$ by other countries (Badan Pusat Statistik, 2017).

Table 1. The 5 Largest World Coffee Producing Countries in 2017

\begin{tabular}{|c|c|c|}
\hline No. & Countries & $\begin{array}{c}\text { Production } \\
\text { (Ton) }\end{array}$ \\
\hline 1. & Brazil & $55,000.000$ \\
\hline
\end{tabular}

\begin{tabular}{|c|c|c|}
\hline No. & Countries & $\begin{array}{c}\text { Production } \\
\text { (Ton) }\end{array}$ \\
\hline 2. & Vietnamese & $25,500.000$ \\
\hline 3. & Colombia & $14,500.000$ \\
\hline 4. & Indonesia & $11,491.000$ \\
\hline 5. & Ethiopia & $6,600.000$ \\
\hline
\end{tabular}

Source: Indonesia Investments

Some of these coffee importing countries sometimes re-export some of the coffee they import, but in small amounts, namely $8 \%$ of all coffee imports in the world (International Coffee Organization, 2018).

Table 2. The 5 Biggest World Coffee Exporting Countries in 2017

\begin{tabular}{|c|c|c|}
\hline No & Countries & $\begin{array}{c}\text { Production } \\
\text { (Ton) }\end{array}$ \\
\hline 1 & Brazil & $34,500.000$ \\
\hline 2 & Vietnamese & $23,200.000$ \\
\hline 3 & Colombia & $12,800.000$ \\
\hline 4 & Indonesia & $6,891.000$ \\
\hline 5 & Honduras & $5,589.000$ \\
\hline
\end{tabular}

Source: Indonesia Investments

For Indonesia, the United States is a vital business and trade partner, in which the United States is the largest non-oil and gas importer after China and Japan from Indonesia. The US is, of course, also Indonesia's largest export 
destination country for coffee. Regarding coffee export activities, the government has implemented several export policies for coffee exporters in exporting coffee to open up Indonesian coffee products' competitiveness in the world. These policies include (Gabungan Eksportir Kopi Indonesia, 2011):

1. Minister of Trade Regulation No. 10/M-DAG/PER/5/2011 regarding export licensing for coffee exporters. In accordance with Indonesia's coffee export trade system, only registered coffee exporters (ETK) and temporary coffee exporters (EKS) can export coffee.

2. Minister of Trade Regulation No. 27/M-DAG/PER/7/2008 article 9 states that the exported coffee must comply with the quality standard stipulated by the Minister of Trade and must be accompanied by a Certificate of Origin (SKA) Form ICO as referred to in the Minister of Trade Regulation concerning the issuance of the certificate of origin for Indonesian export goods.

In this policy, there are regulations and forms for coffee quality standards that comply with the coffee quality standards implemented by the International
Coffee Organization (ICO). The cooperation in exporting Indonesian coffee to the United States itself was already underway when Indonesia officially joined the International Coffee Organization in 1963. The market share of Indonesian coffee in the United States is quite good; changes in the competitiveness of Indonesian coffee in the United States coffee market continue to increase.

During the 2012-2017 period, the total export value of coffee produced by Indonesia to the United States was around 65 thousand tons annually, with an average annual export value of USD 250 million. Even though there are fluctuations every year, Indonesia's coffee exports to the United States are considered stable because each year's differences do not show too large a number. During that period, the total export value of Indonesian coffee to the United States in 2012 was 69.7 thousand tons, with the highest export value occurring in the same year, amounting to USD 330.8 million. Meanwhile, the decline in exports occurred in 2014, with exports totaling 58.3 thousand tons. Besides, data from the Central Bureau of Statistics revealed that Indonesia experienced the lowest export income from coffee in 2013, 
with a value of USD 207 million (Badan Pusat Statistik, 2017).

Table 3. Development of Indonesian Coffee Exports to the United States (2012-2017)

\begin{tabular}{|c|c|c|}
\hline Years & $\begin{array}{c}\text { Net } \\
\text { Weight } \\
\text { (Thousand } \\
\text { Tons) }\end{array}$ & $\begin{array}{c}\text { Free On } \\
\text { Board } \\
\text { Value (USD } \\
\text { Millions) }\end{array}$ \\
\hline 2012 & 69,7 & 330,8 \\
\hline 2013 & 66,1 & 207,0 \\
\hline 2014 & 58,3 & 295,9 \\
\hline 2015 & 65,5 & 281,1 \\
\hline 2016 & 67,3 & 270 \\
\hline 2017 & 63,2 & 256,4 \\
\hline
\end{tabular}

Source: Central Bureau of Statistics

\section{Increasing the Quality and} Quantity of Coffee Production

Indonesia could produce a total of 690,675 tons of coffee in 2012. From 2012-2017, the largest production occurred in 2012, with 661,429 tons produced by smallholder coffee plantations, 13,577 tons of large state plantations, and 15,759 tons produced by large private plantations. Also, in that year, Indonesia exported 69,700 tons to the United States. In 2017, Indonesia had coffee farming land of $1,227,787$ hectares, with a total production of 637,455 tons and a total export of 63,200 tons to the
United States (Badan Pusat Statistik, 2017)

With the continuous development of the processed coffee industry, the government must strive to improve the quality of human resources, capital, and science and technology to catch up with other world coffee giants and create more competitive competitiveness. Through the Ministry of Agriculture of the Republic of Indonesia, the Indonesian government strives to continue to advance innovation and technology. Through the 20152019 Strategic Plan compiled by the Ministry of Agriculture of the Republic of Indonesia in 2015, the following are efforts undertaken by the Indonesian government (Kementrian Pertanian Republik Indonesia, 2015) :

1. Increasing research capacity and facilities in the agricultural sector

2. Increasing research that uses the latest technology to find a breakthrough to increase the productivity of seeds/plant seeds

3. Expanding the scope of research starting from production inputs, land effectiveness, cultivation techniques, postharvest techniques, processing 
techniques, to packaging and marketing techniques

4. Increasing technology dissemination to farmers widely

5. Fostering advanced farmers as actors in the development and application of new technologies at the field level

\section{Indonesian Coffee Branding}

The birth of the Third Wave Coffee era certainly had a considerable influence in the world of coffee, and specialty coffee has begun to be recognized, with the details that the coffee is of the best quality. The selection of specialty coffee also allows international coffee consumers, especially the United States, to get detailed information about the coffee they consume. This fact also opens up opportunities for the development of Indonesian coffee as an export commodity, and of course, Indonesian coffee can help increase country branding for Indonesia.

Indonesian specialty coffee has many choices compared to other producing countries, such as Brazil, Vietnam, or Colombia, which have always been Indonesia's competitors as a coffee producing country for decades. However, Indonesia has not yet focused on developing coffee branding has resulted in the exported coffee not involving Indonesia's name as the export results' landlord.

\section{Indonesia Labeling}

From the previous explanation, Sumatran coffee is known as Kopi Sumatra or Javanese coffee is known as Kopi Jawa; hence, there needs to be a change in branding. There needs to be Indonesian information in every coffee tied to a regional name, such as Balinese coffee being re-branded as Indonesian Balinese coffee. It aims to improve information and give consumers more confidence if they want to supply specialty coffee from Indonesia. This re-branding will also affect other export products because if the country's branding through Indonesian coffee is successful, it may increase the United States consumers' interest in other Indonesian products.

As already stated, regarding the importance of the label or branding "Indonesia" in Indonesian coffee marketing, on August 9, 2019, an interview was conducted at the Ministry of Trade of the Republic of Indonesia with Mr. Abu Amar, as Head of the Sub-Directorate for Promotion of American and European Regions, Directorate of Promotion and Image Development, Directorate General of National 
Export Development, Ministry of Trade of the Republic of Indonesia and Mr. Yafrizal Daniel, as Staff of the Directorate of Promotion and Image Development, Directorate General of National Export Development, Ministry of Trade of the Republic of Indonesia. Both stated that in the specialty coffee case, the Ministry of Trade of the Republic of Indonesia had strategic steps for branding Indonesian coffee in the United States. First, nation branding will be carried out to present Indonesia in each coffee, which initially only used the region's name or the name the coffee came from (Amar \& Daniel, 2019).

In an interview at the Ministry of Industry on August 2, 2019, with Mr. Mogadishu Djati Ertanto as Deputy Director of Soft drink and Horticulture Based Industry, it was also explained the importance of Indonesian branding in the coffee products being promoted. According to Mr. Mogadishu, Indonesia branding is essential for the country's brand image or country image in the international world so that Indonesia is better known for its quality natural products; not only as a tourist destination for the international community but also to open market opportunities to improve Indonesia's economy through the coffee industry (Ertanto, 2019).

In line with Mr. Mogadishu's statement, during a visit to the Indonesian Coffee Exporters Association (AEKI) on August 5, 2019, at the Coffee Building, Jl. RP Suroso, RT.2/RW.2, Gondangdia, Menteng District, Central Jakarta City, Special Capital Region of Jakarta, Mr. Hadi Mardiansyah was interviewed as AEKI Administration \& Finance Staff, who also served as AEKI Coffee Class Coordinator (PPKI), stated that there must be positioning of Indonesia's name in branding to make Indonesian coffee more familiar and define different coffees' various characteristics owned by Indonesia (Mardiansyah, 2019).

\section{Organizing an International Event/Trade Expo in Indonesia}

One of Indonesia's culinary events is the Trade Expo Indonesia. At this event, Indonesia's superior products that can meet the world's export needs are introduced, such as wood crafts, batik, tea, honey, and of course, coffee. Starting in 1985, this event, which was developed through the Ministry of Trade of the Republic of Indonesia in cooperation with various parties, has succeeded in attracting international interest, not 
only in culture but also regarding natural products produced and continuously developed. With this exhibition, the country has the goal of increasing international interest in importing Indonesian goods and increasing Indonesia's export figures. It is also to increase the level of local companies to reduce the number of unemployed and become a solution because it will be able to open new jobs (Kementrian Perdagangan Republik Indonesia, 2019)

In 2017, Indonesia's trade balance reached USD 17.3 billion, and in 2018, through the Ministry of Trade of the Republic of Indonesia September 2018, a surplus of USD 122 billion was recorded, growing by $9.2 \%$. It showed an increase in terms of exports (Kementrian Perdagangan Republik Indonesia, 2019)

As Head of the Sub-Directorate for Promotion of American and European Regions, Directorate of Promotion and Image Development, Directorate General of National Export Development, Ministry of Trade of the Republic of Indonesia, Mr. Abu Amar provided information about the Trade Expo Indonesia. It is one of the means for farmers, local and foreign entrepreneurs as a forum to make it easier in terms of information so that an agreement is made for cooperation. As before, the 2019 Trade Expo Indonesia was held from October 16-20, 2019, at ICE BSD Tangerang (Amar \& Daniel, 2019).

\section{Attending the Event/Trade Expo in the United States}

Suppose the Indonesian Trade Expo held domestically is to open up domestic business actors' opportunities to expand their networks to national and international markets. In that case, Indonesia also participates in events or trade fairs in the United States to further introduce Indonesian coffee in the United States.

Quoted from Gaeki.or.id, Nus Nuzulia Ishak, as Director-General of National Export Development, the Ministry of Trade of the Republic of Indonesia, stated that Indonesia and the United States signed a Memorandum of Understanding (MoU) worth USD 18 million (Rp. 240 billion) for coffee exports to the United States (Gabungan Eksportir Kopi Indonesia, 20016)

With the facts explained, it can be said that coffee is one of Indonesia's superior products. During the five periods of 20122017, coffee was included in the top 25 of Indonesia's primary export 
commodities to the world, and coffee became one of the leading export commodities for Indonesia. The trend in the value of coffee trade during this period was positive, with exports to the United States valued at USD 330.8 million in 2012 and USD 256.4 million in 2017. Although export revenues decreased, it was also due to increased national coffee consumption.

With these data and facts, it is necessary to take several steps in facing the competition in world coffee exports, mainly opening up more of the United States market share as follows:

1. Improvement of the quality of coffee commodity production

2. Adjustment of coffee types to market demand and promotion to increase domestic consumption and exports

By implementing the strategy for increasing exports described, Indonesia must also implement a promotional strategy to attract more United States consumers to increase coffee exports from Indonesia. The steps that can be taken are:

a) Attending the Specialty Coffee Association of America (SCAA)/Specialty Coffee Association (SCA) exhibition b) Organizing an education and knowledge program about Indonesian coffee to make baristas and coffee lovers familiar with, getting to know, and understanding Indonesian coffee's characteristics

c) Conducting knowledge programs for buyers to maintain government relations and attention, both to importers, baristas, and roasters, each of which contributes to shaping the Indonesian coffee exports' image and value

d) Collaborating with existing Indonesian Chambers of Commerce in the United States and other associations to build relationships with local business chains and lobby and leverage their experience and expertise to provide training/ workshops on export, import, and entrepreneurial skills for the Indonesian Diaspora.

Indonesia's cooperation with the United States in terms of coffee export-import has at least three positive impacts for the two countries, namely:

1. As an exporting country, Indonesia will get budget revenue and increase its foreign exchange in exporting coffee to the United States and improve 
Indonesia's name as a natural product-producing country in the international market.

Table of Indonesian Export Revenue Value FOB Values (USD Thousands)

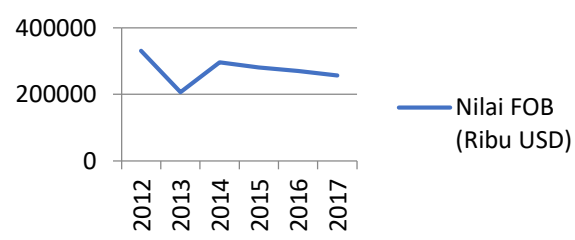

Data Source: Data Processing

2. As one of the world's superpowers, the United States is a country with a large need for coffee. By importing coffee from Indonesia, the United States can meet its country's coffee needs.

3. Indonesia and the United States can build greater economic cooperation and strong bilateral relations.

\section{CONCLUSION}

The various problems faced by Indonesia in increasing coffee production and exports will, of course, be resolved gradually, starting with the regulatory policy issued by the Indonesian government through the Ministry of Trade of the Republic of Indonesia, namely Regulation Number 26/M-DAG/ PER/12/2005. This provision was replaced by Regulation Number 27/M-DAG/PER/7/2008. Then, after a year, in 2009, the regulation changed to 41/M-DAG/PER/9/2009. Coffee Export Regulations were revised in 2011 with regulation Number 10/M-DAG/PER/5/2011 (Kementrian Perdagangan Republik Indonesia, 2011).

Human resource development is also a focus. Providing complete information to coffee farmers is considered necessary, considering current technological advances that can help to develop coffee plants to get high-quality production results.

On the other hand, coffee exports will undoubtedly affect the promotional strategy that is implemented. The first focus that needs to be studied is coffee labeling or branding because so far, the world market and the United States have indirectly recognized coffee by name; for example, at this time, Javanese coffee or Sumatran coffee is known as Javanese and Sumatran coffee only. Re-branding to include the name "Indonesia" as the parent of Sumatra and Java itself is crucial. Mr. Abu Amar, as Head of the Sub-Directorate for Promotion of American and European Regions, Directorate of Promotion and Image Development, Directorate General of National Export 
Development, Ministry of Trade of the Republic of Indonesia and Mr. Yafrizal Daniel, as Staff of the Directorate of Promotion and Image Development, Directorate General of National Export Development, Ministry of Trade of the Republic of Indonesia, stated that the rebranding steps would be carried out in stages; Indonesia will carry out nation branding for coffee produced by Indonesia as an exported commodity (Amar \& Daniel, 2019).

The Indonesian coffee promotion in the United States is also crucial to increase the United States consumers' interest in Indonesian coffee. One of the biggest trade events that discuss coffee in the United States is the SCAA (Specialty Coffee Association of America), which has now changed its name to the Specialty Coffee Association due to the joining of two organizations: the American and European Specialty Coffee Association.

\section{BIBLIOGRAPHY}

Subagyo, A. (2019). Global Economic.

Aimon, H. (2013). Prospek Perdagangan Luar Negeri Indonesia - Amerika Serikat Dan Kurs. Jurnal Kajian Ekonomi, 1(2), 7104.
Amaral, G., Bushee, J., Cordani, U. G., KAWASHITA, K., Reynolds, J. H., ALMEIDA, F. F. M. D. E., de Almeida, F. F. M., Hasui, Y., de Brito Neves, B. B., Fk, R. A., Oldenzaal, Z., Guida, A., Tchalenko, J. S., Peacock, D. C. P., Sanderson, D. J., Rotevatn, A., Nixon, C. W., Rotevatn, A., Sanderson, D. J., ... Junho, M. do C. B. (2013). Basic of Social Research. In Journal of Petrology (Vol. 369, Issue 1). https://doi.org/10.1017/ CBO9781107415324.004

Anak Agung Banyu Perwita \& Yanyan Mochamad Yani. (2006). Pengantar Ilmu Hubungan Internasional. Remaja Rosdakarya.

Badan Pusat Statistik. (2019). Ekspor Kopi Menurut Negara Tujuan Utama, 2000-2018. https://www.bps.go.id/ statictable/2014/09/08/1014/ ekspor-kopi-menurut-negaratujuan-utama-2000-2018.html Bakri. (2018). Kopi Gayo Jadi Primadona di AS. Serambinews. Com. https://aceh.tribunnews. com/2018/04/23/kopi-gayojadi-primadona-di-as

Bruce Russett \& Harvey Starr. (1996). World Politics: The Menu For Choice. W. H Freeman Company. 
Cahya, K. D. (2018). Kopi Sumatra Paling digemari di Seluruh Starbuks Dunia. Kompas.Com. https://lifestyle.kompas.com/ $\mathrm{read} / 2018 / 03 / 07 / 061400420 /$ kopi-sumatra-paling-digemaridi-seluruh-starbucks-dunia

Cipto, B. (2018). Politik Global Amerika. The Phinisi Press Yogyakarta.

Departemen Perindustrian. (2009). Roadmap Industri Pengolahan Kopi. Direktorat Jenderal Industri Agro Dan Kimia Departemen Perindustrian, 1-5. http:// agro.kemenperin.go.id/420ROADMA P - INDUSTR I PENGOLAHAN-KOPI

DEPPERINDAG. (2004). Warta Ekspor (No.1/TahunXXXIFebruari 2004).

Direktorat Jenderal Pengembangan Ekspor Nasional Kementerian Perdagangan. (20011). Membangun "Nation Branding. Warta Ekspor.

Direktorat Jenderal Perkebunan Republik Indonesia. (2016). Statistik Perkebunan Indonesia Komoditas Kopi. http:// ditjenbun.pertanian.go.id

Edited by Frost Warwick and Laing Jennifer. (2018). Exhibitions, Trade Fairs and Industrial
Event. Routledge, Taylor and Francis Grup.

Gabungan Eksportir kopi Indonesia. (n.d.). Peraturan Ekspor. Peraturan Ekspor. https://gaeki. or.id/ketentuan-ekspor-kopi/ Hardiwinata, B. S. (2002). Politik Bisnis Internasional. Kanisius Media.

Hariyanti, D. (2018). Potret Historis Kopi Indonesia Dikemas dalam Buku. Katadata. Com. https://katadata.co.id/ berita/2018/12/12/potrethistoris-kopi-indonesiadikemas-dalam-buku

Huda, N. (2015). Ilmu Negara. Rajawali Pers.

Indonesia Investment. (2017). Kopi. Indonesia Investment. https:// www.indonesia-investments. com/id/bisnis/komoditas/kopi/ item 186

ITPC-Chicago. (2013). Market Brief Kopi. 1-38.

Kementerian Perdagangan Republik Indonesia. (2018). Warta Ekspor.

Kementerian Perdagangan Republik Indonesia. (2008). Peraturan Menteri Perdagangan Republik Indonesia. Peraturan Perundang-Undangan Perdagangan Republik Indonesia, Vol 49, 69-73. 
Kementerian Perdagangan Republik Indonesia. (2005). Peraturan Menteri Perdagangan Republik Indonesia Nomor: 41/M-DAG/ PER/9/2009. 1934, 1-5.

Kementerian Perdagangan Republik Indonesia. (2011). 10/M-Dag/ Per/5/2011. 2005.

Kementerian Perindustrian Republik Indonesia. (2016). Wujudkan hilirisasi industri berbasis sumber daya alam. Media Industrri, 01, 1-68. http://www.kemenperin.go.id/ download/11419

Kementerian Pertanian Republik Indonesia. (2013). Statistik kopi Indonesia 2018. In Journal of Petrology (Vol. 369, Issue 1). https://doi.org/10.1017/ CBO9781107415324.004

Kementerian Pertanian Republik Indonesia. (2013). Statistik kopi Indonesia 2016. In Journal of Petrology (Vol. 369, Issue 1). https://doi.org/10.1017/ CBO9781107415324.004

Kementerian Pertanian Republik Indonesia. (2017). Buka Peluang Usahan IKM kopi.

Kementrian Perdagangan Republik Indonesia. (2005). Permendag Nomor 38 Tahun 2005.

Kementrian Perindustrian Republik Indonesia. (2016). Harga Kopi
Dunia Jeblok, Eksportir Lirik Pasar Domestik. Kementrian Perindustrian Republik Indonesia. https://kemenperin. go.id/artikel/14428/HargaKopi-Dunia-Jeblok,-EksportirLirik-Pasar-Domestik.

Komara, E. (2011). Filsafat Ilmu dan Metodologi Penelitian. PT Refika Aditama.

Kompasiana.com. (2015). Mengurai Biji Kopi Indonesia: Centhini, Multatuli, sampai Gaya Hidup Masa Kini. Kompasiana.Com. https://www.kompasiana.com/ damarjuniarto/54f712b9a33 $311 \mathrm{ab} 1 \mathrm{~d} 8 \mathrm{~b} 4792 /$ menguraibiji-kopi-indonesia-centhinimultatuli-sampai-gaya-hidupmasa-kini.

Krugman and Obsfelt. (1991). Ekonomi Internasional: Teori dan kebijakan. Raja Grafindo Persada.

Kustiari, R. (2016). Perkembangan Pasar Kopi Dunia dan Implikasinya bagi Indonesia. Forum Penelitian Agro Ekonomi, 25(1), 43. https:// doi.org/ 10.21082 / fae . v25n1.2007.43-55

L., M. (2002). Metode Penelitian Kualitatif. PT Remaja Rosdakarya. 
M.S, A. (2000). Seluk Beluk Perdagangan Luar Negeri, PPM, Jakarta, kontak Dagang, Ekspor. PPM.

Margaret P. Karns \& Mingst Katren A. (2010). International Organization: The Politics and Processes of Global Governance. Lynne Rienner Publishers.

Maskyur, S. (2016). Kopi Indonesia di SCAA Atlanta. Gabungan Eksportir Kopi Indonesia. https://gaeki.or.id/kopiindonesia-di-scaa-atlanta/

Mas'oed, M. (2014). Ekonomi Politik Internasional Pembangunan. Pustaka Belajar.

Mazrieva, E. (2016). 17 kopi Indonesia siap jadi Primadona di Expo Amerika. VOA INDONESIA. https://travel. tempo.co/read/765017/kopigunung-puntang-juaraikontes-kopi-di-atlanta-amerika

Mochtar Mas'oed \& MacAndrews Colin. (2011). Perbandingan Sistem Politik. Gajah Mada University Press.

Mortimer, E. (2012). Global Political Economy. In Australian Journal of International Affairs (Vol. 66, Issue 3). https://doi.org/10.1080 /10357718.2012.681993

Neilson, J., Labaste, P., \& Jaffee, S. (2015). Towards the More
Competetive and Dynamic Chain Value for Indonesia Coffee. February 2015. https://doi.org/10.13140/ RG.2.1.1010.9844

Porter, M. E. (2011). The Competitive Advantage of Nations. Simon and Schuster.

Pusat Data dan Sistem Informasi Pertanian. (2016). Outlook Kopi 2016. 93.

Rana, K. S., \& Chatterjee, B. (2011). Chapter 1: Introduction: The Role of Embassies. Economic Diplomacy: India's Experience, 3-25.

Rangkuti, F. (2011). Dongkrak Penjualan melalui marketing strategy \& competitive positioning. PT Gramedia Pustaka Utama Kompas Gramedia.

Ravertz, J. R. (2014). Filsafat Ilmu, Sejarah \& Ruang lingkup bahasan. Pustaka Belajar.

Richard, L. (1985). Diplomacy and Intelligence During the Second World War. Diplomacy and Intelligence During the Second World War. https://doi.org/10.1017/ cbo9780511522932

Robert Jakson \& Georg Sorensen. (2013). Pengantar Studi Hubungan Internasiona,. Teori 
dan Pendekatan (Edisi kelima). Yogyakarta : Pustaka Belajar.

Rourke, J. T. (1995). International Politics on the World Stage. Connecticut: Dushking Publishing Group.

Sabaruddin, S. S. (2017). Grand Design Diplomasi Ekonomi Indonesia: Sebuah Pendekatan Indeks Diplomasi Ekonomi. Jurnal Ilmiah Hubungan Internasional, 12(1), 69. https://doi.org/10.26593/jihi. v12i1.2545.69-90

Said, E. W. (2019). Imajinasi Intelektual. Circa.

Simamora, S. D. (2014). Market Brief: Langkah dan Strategi Ekspor ke Uni Eropa: Produk Kopi. Eu Active, Juli 2014.

Simic, R., Bolfek, B., \& Stoic, A. (2008). Document management system as source of competitive advantage. Proceedings of New Ways in Manufacturing Technologies 2008, Presov, Slovak Republic, 343-347.

Siregar, T. (2015). JPW Coffee di Trade Expo Indonesia 2015. JWP Coffee. https://www. jpwcoffee.com/jpw-coffee-ditrade-expo-indonesia-2015

Solopos.com. (2015). FILM DOKUMENTER : Populerkan Kopi RI, Aroma of Heaven
Tayang di AS. Solopos.Com. https://www.solopos.com/filmdokumenter-populerkan-kopiri-aroma-of-heaven-tayang-dias-593805

Studi, P., \& Anggraini, D. (2006). Faktor-Faktor Yang Mempengaruhi Permintaan Program Pascasarjana FaktorFaktor Yang Mempengaruhi Permintaan. 1-99.

Sukirno, S. (2012). Pengantar Teori Makro Ekonomi (Edisi Kedu). Raja Grafindo Persada.

Suryadi, B. U. (2017). Dasar-dasar Hubungan Internasional. Prenada Media.

Sutriyanto, E. (2019). Terbentuk Forum Sinergi Komunitas Hulu Hilir Kopi untuk Kemajuan Kopi Indonesia Artikel ini telah tayang di Tribunnews.com dengan judul Terbentuk Forum Sinergi Komunitas Hulu Hilir Kopi untuk Kemajuan Kopi Indonesia. Tribunnews.Com. https://www.tribunnews.com/ nasional/2019/04/13/terbentukforum-sinergi-komunitas-huluhilir-kopi-untuk-kemajuankopi-indonesia

Tempo.com. (2016). Kopi Gunung Puntang Juarai Kontes Kopi di Atlanta Amerika. Tempo. Com. https://travel.tempo.co/ 
read/765017/kopi-gunungpuntang-juarai-kontes-kopidi-atlanta-amerika

Tim Program Pascasarjana. (2012). Buku Pedoman Penulisan Tesis dan Disertasi. Program Pascasarjana Universitas Negeri Jakarta 2012.

Tokan, P. T. (2016). Komunikasi Politik. PT Gramedia Pustaka Utama Kompas Gramedia.

Tools, J. M. (2017). MODEL PASOKAN KOPI ACEH: BEBERAPA SIMULASI KEBIJAKAN. 7(1), 45-56.

Visensio, D. (2018). Teori Hubungan Internasional (Perspektifperspektif Klasik) (Edisi Revisi). Airlangga University Press.

Voeltz, R. (2005). (Oxford Historical Monographs.). The American Historical Review, 110(5), 16171618. https://doi.org/10.1086/ ahr.110.5.1617a
Volsi, B., Telles, T. S., Caldarelli, C. E., \& da Camara, M. R. G. (2019). The dynamics of coffee production in Brazil. PLoS ONE, 14(7), 1-15. https:// doi.org/10.1371/journal. pone.0219742

William A. Rugh. (2009). The Case for Soft Power. Toward a New Public Diplomacy, 40(2), 5,6. https://doi.org/ papers $2: / /$ publication / uuid/777B1BB4-E618-47569E65-70412B593830

Yuliandri, M. T. (2015). SEJARAH "FIRST, SECOND AND THIRD WAVE COFFEE." Majalah Otten. https://majalah. ottencoffee.co.id/sejarah-firstsecond-and-third-wave-coffee/ 